\title{
The Bases for Projecting Individual Educational Trajectories of Future Teachers
}

\author{
Veronika B. Veretennikova*(a), Elvira Sh. Urazova (b), Olga F. Shikhova (c) \\ (a), (b) Kazan Federal University, 420008, Kazan (Russia), 18 Kremlyovskaya street \\ (c) Kalashnikov Izhevsk State Technical University, 426069, Izhevsk (Russia), 7 Studencheskaya street
}

\begin{abstract}
The implementation of the Federal State Educational Standard of Higher Education $3++$ requires devising individual curricula for students with regard not only to the demands of the federal and regional labor markets, as well as of the academic community, but also to the educational needs and interests of students themselves. In our opinion, at a time of shortage of teaching staff, including the system of preschool education, the devising of individual curricula and related to their implementation individual educational trajectories of students will increase motivation for learning that provides them with the opportunity to purposefully choose an individual path of development and self-improvement.

The aim of the given paper is to present the bases for projecting individual educational trajectories of future teachers of preschool organizations, consideration of which will create the most favorable conditions for motivation, self-management and self-development of students; will determine effective methods and technologies of their education by individual educational trajectories. The methodological framework for determining the bases for projecting future preschool teachers' individual educational trajectories includes systematic and competency-based approaches. The key method of the research is the general scientific method of analysis of scientific pedagogical literature and regulatory documents in the field of higher and preschool education. To conduct pedagogical expertise of the bases for projecting individual educational trajectories, the method of group expert assessment is used. The presented bases for the projecting of future teachers' individual educational trajectories comprise the consistency of the requirements of basic regulatory documents in the field of preschool education and provide a more comprehensive approach to the selection and contents of elective modules, as well as increase students' motivation for learning and self-improvement in the professional field. The research materials can be useful for university administration and teachers while creating individual educational trajectories for bachelors who are professionally oriented on teaching in preschool establishments.
\end{abstract}

Keywords: federal state educational standard of higher education, individual curriculum, individual educational trajectory, professional standard, preschool teacher, professional pedagogical competence.

(C) 2020 Veronika B. Veretennikova, Elvira Sh. Urazova, Olga F. Shikhova

This is an open access article distributed under the terms of the Creative Commons Attribution License (CC BY 4.0), which permits unrestricted use, distribution, and reproduction in any medium, provided the original author and source are credited.

Published by Kazan federal university and peer-reviewed under responsibility of IFTE-2020 (VI

International Forum on Teacher Education)

\footnotetext{
* Corresponding author. E-mail: veronika.veretennikova.71@mail.ru
} 


\section{Introduction}

According to the Federal State Educational Standard of Higher Education (FSES HE $3++$ ), all components of the educational process should be aimed at the student's acquisition of universal, general professional and professional competencies necessary for them to perform certain labor functions at the future workplace.

Individualization of educational process offers a student, in particular a future teacher, the opportunity to choose an individual path in education and further professional activity. The success of this choice largely depends on the development of a well-balanced individual curriculum (IC) for the student and its implementation within individual educational trajectory (IET).

Facing the choice, the student shapes his/her own "educational model" of a future teacher who possesses a certain range of the most significant for him/her competencies, ensuring the effective fulfillment of tasks in the future professional activity. Moreover, an individual curriculum can also contribute to the accelerated training of future teachers, in case its content includes the long-term needs of preschool education both at the federal level and at the level of a specific region.

The solution to this problem necessitates a relevant choice of methodological bases for projecting individual curricula and corresponding individual educational trajectories of students.

The projecting bases are considered as general goals and factors that determine the organizational and logical structure of training within individual curricula as well as its characteristics. In our opinion, to correctly select and theoretically verify them it is advisable to study the experience of individualization of education and the ways of its implementation in the learning process of students oriented in teaching.

\section{Purpose and objectives of the study}

The aim of our paper is to present the bases for projecting individual educational trajectories of students training in the field of study 44.03.01 “Teacher Education" (major "Preschool Education"), which are determined by analyzing scientific pedagogical literature and regulatory documents in the field of higher and preschool education and verified by the method of group expert assessment.

\section{Literature review}

The state program of the Russian Federation "Development of Education" for 2018-2025 years underlines an idea of introducing individual curricula for undergraduate students as a means of individualization of education and implementing their transition to individual educational trajectories in the educational process.

The analysis of scientific pedagogical literature (Postnikova, 2013; Zhukova, 2006) demonstrates that individual curricula are regarded by researchers as the basis for projecting a student's individual educational trajectory that regulates his/her actions in achieving educational goals (Kunash, 2013).

Successful practice of projecting individual educational trajectories through module-based learning is presented in the research work of Maskaeva (2011). The researcher offers the projecting algorithm that indicates successive actions of the teacher and students. The teacher divides the course into basic (mandatory) and variable (elective) modules, shapes their 
composition: goals, content, methods, technologies, forms, tools, testing and assessment materials. The teacher's tasks also include managing students' learning activity within the framework of variable modules and tracking their progress according to individual educational trajectories (Maskaeva, 2011).

As for students, their activity is connected with the study of mandatory modules and preparation for the selection of course units of interest for further learning. In addition, students select variable modules, and with the assistance of a teacher determine the ways of arranging their study, including the process of compiling a professional portfolio.

Sazonov (2011) also offers an innovative form of organizing an individually-oriented educational process within the framework of a modular plan. A modular plan may include disciplines studied by students during next several semesters. The implementation of a modular plan, which determines the individualization of training, includes students' selection of training modules, approving them with the teacher, building an individual schedule.

Researchers aptly note that the appropriate choice of a student's personal and professional development trajectory urges to take into account his/her individual characteristics, educational needs and interests.

In this regard, Lomakina's work (2013) demonstrates the practice of choosing individual educational trajectories by students, which are realized on the discipline platform, that includes all the variety of in-depth and enriched content of education, types and forms of the subject material, rational techniques of learning activity, assessment forms of learning outcomes, forms of self-study, as well as levels and ways of getting education.

The author points out that projecting individual educational trajectories is based on the following characteristics of a student:

- an inclination for a certain type of activity: technical creativity and innovative activity in engineering and technology (creative and innovative person); scientific creativity (innovative and creative person); public social activity (public and innovative person); leadership (organizational and innovative person);

- the need for professional self-determination, involving the formation of professional intentions, professional training, professionalization and professional adaptation, professional skills, partial or full realization in professional engagement;

- $\quad$ readiness for professional self-determination, which is determined by motivation, that inspires and stimulates the person to reach the goal and contributes to his/her development.

Significant is the work of Gayazov (2010), which describes individual educational trajectory as a consistent implementation of student's training elements that comprise several areas: content (implementation of the educational program); activity (implementation through pedagogical technologies); process (determining the organizational aspect of the individualization process). As the author notes, a distinguishing feature of such a trajectory is that it is characterized by a certain sequence of learning elements that allows students to achieve their own educational goals that correspond to their abilities, capabilities, motivation, interests, and are implemented with the coordinating, organizing, and consulting activities of the teacher (Zeer \& Zhurlova, 2017). 
In contemporary scientific publications the term "individual educational path" is frequently used. Generally, an individual educational path is treated as a students' activity within the educational program that involves the choice of teachers and selection of academic disciplines as well as provides their academic mobility. An individual educational path is created with regard to individual and professional requests of the person, contributing to the development of student's subject position, self-actualization and self-realization (Sagimbaeva, 2015).

In her study, Sagimbayeva (2015) presents the stages of developing an individual educational path:

1. Setting learning objectives in accordance with the educational standard and individual goals of each student.

2. Choice of teaching technologies within the educational path and development of a mechanism for managing learning and cognitive, scientific and other activities of students at the university.

3. Selection of subject content that meets the interests and needs of students.

4. Development of a "routing" map of the path, as well as the plan and procedures of "passing the route".

5. Tutor support of an individual educational path, which according to the level of training guarantees the student an acquisition of the required number of credits to complete education, and promoting adaptation to academic life. As a rule, a tutor is an experienced teacher, who provides students with necessary information while selecting programs, modules and combinations of modules that meet students' academic interests and commensurate with their abilities.

6. Diagnosing the effectiveness of students' learning as they advance on the individual educational path and making necessary alterations to it.

\section{Reflection of student's performance.}

The analysis of foreign sources (Spirina \& Sagoyakova, 2014) demonstrates that Western European and American educational models are focused mostly on the student. Within the framework of these models a student stands out as the subject of education and can independently determine the content, pace and trajectories of his/her learning. In the USA, the methodological bases of individualization of education include:

- a personalized system of instruction, which is based on the concept of psychological behaviorism (Bruner, Skinner), suggests that educational material should be delivered to the student in various ways and the training is organized in relation to his individual characteristics;

- the need for self-realization, freedom of expression, creative activity, personal growth, when learner's personality is considered as an integral unity, based on the concept of humanistic psychology (Combs, Maslow, Allport, Rogers);

- theories of cognitive sociology and management psychology; for example, Tajfel's theory of social justice, which describes the dependence of human behavior on his/her subjective perceptions, while the development of his/her personality in learning is determined by the development of thinking in the ongoing information exchange. 
The authors single out significant components of the tutor's work, which provide individualization of learning. They are:

- entrance diagnostics, which aims at identifying the interests, motives, orientation of the student's personality, their abilities, current training level, the degree of organization of educational activity;

- joint goal-setting, which involves identification of priority areas of learning based on examining the general content of the discipline and revealing individual problems of students;

- $\quad$ proposing students a space of alternatives within the framework of the academic discipline, which comprises content, pace, scope, depth of mastery of the material, methods of academic work, as well as the use of technologies aimed at encouraging independence and active performance of students, developing their ability for goal-setting and reflection, forming a subject position during educational process and their own style of learning;

- system of knowledge control, which is focused primarily on individual assessment principles (Spirina, Sagoyakova, 2014).

Here, we should note the successful experience of teachers from the University of Trento, Italy, and the Ufa State Aviation Technical University, Russia. The researchers Molinari, Trevisan (Italy) and Bogdanova, Akhmetova (Russia) in vocational education and training group students with regard to their knowledge level that helps to make an adequate choice of individual curriculum within the framework of the basic educational program taking into account the needs of participants of the educational process (Molinari \& Trevisan, 2013).

Dmitriev (2010) describes the individualization of the educational process in US universities, in which student groups are assembled for one term to study specific disciplines. Moreover, students are given the right to choose the field of knowledge that responds to their educational interests, as well as the opportunity to change their area of specialization, extending the period of study at the university.

A number of researchers, such as Choi, Lindquist and Song (2014), Loyens, Rikers and Schmidt (2006), associate the success of the individualization process with the ability of students for self-management that increases their interest and motivation. In this regard, they point out the importance of teachers' readiness to change existing teaching models in order to create favorable conditions for self-management of students in the training process.

As it is noted in Langshaw's work (2017), student self-government is a valuable tool for the university, which orients them towards a more suitable learning path than the one determined in the traditional curriculum.

In the same vein are carried out the researches of Boyer, Langevin and Gaspar (2008) and Phillips, Turnbull and He (2015), in which the content of the curriculum and training strategies are targeted at encouraging academic achievements of students through self-management.

Works of Brockett and Hiemstra (1991) and Stockdale (2003) examine the process of learning self-management by a student. The process is considered as self-directed learning, designed to support the student and self-evaluate the learning, as well as track such individual characteristics as initiative, self-efficacy and motivation.

Thus, the analysis of the scientific pedagogical literature shows that researchers frequently indicate the following as the bases for projecting individual educational trajectories for students: a module-based curriculum; multilevel content of 
education; individual goals and educational interests of the student; student's performance level; student's inclination for a certain type of activity; method of teaching an educational material.

However, despite the abundance of studies, they do not consider the problem of projecting individual educational trajectories in terms of the convergence of educational goals at the federal, regional, university levels in combination with individual goals of students. Little attention is paid to the labor market demands where a university graduate will be wanted as a young specialist.

The bases for projecting individual educational trajectories of students, presented in this paper, are treated as systemforming factors of the process of individualization of future preschool teachers training by implementing the Federal State Educational Standard of Higher Education (FSES HE $3++$ ) in higher educational institution in accordance with the requirements of the Professional standard "Teacher" and educational needs of students taught based on an individual curriculum.

\section{Methodology}

The bases for projecting individual educational trajectories of future preschool teachers. In accordance with the Federal State Educational Standard of Higher Education $3++$, it is advisable to implement the basic professional educational program of higher education of bachelor's degree through engaging an individual curriculum, based on which an individual educational trajectory of student is designed.

Projecting an individual educational trajectory requires fulfilling a certain preparatory work by teachers and university administration. Particularly, in order to establish an efficient organizational and logical structure of students' training according to individual educational trajectories and state their main characteristics, a reasonable choice of methodological bases for projecting an individual educational trajectory is required.

The model presented in Figure 1 includes the bases for projecting individual educational trajectories of students of the Kazan (Volga Region) Federal University (KFU) enrolled in the field of study 44.03.01 "Teacher Education" (major "Preschool education") 


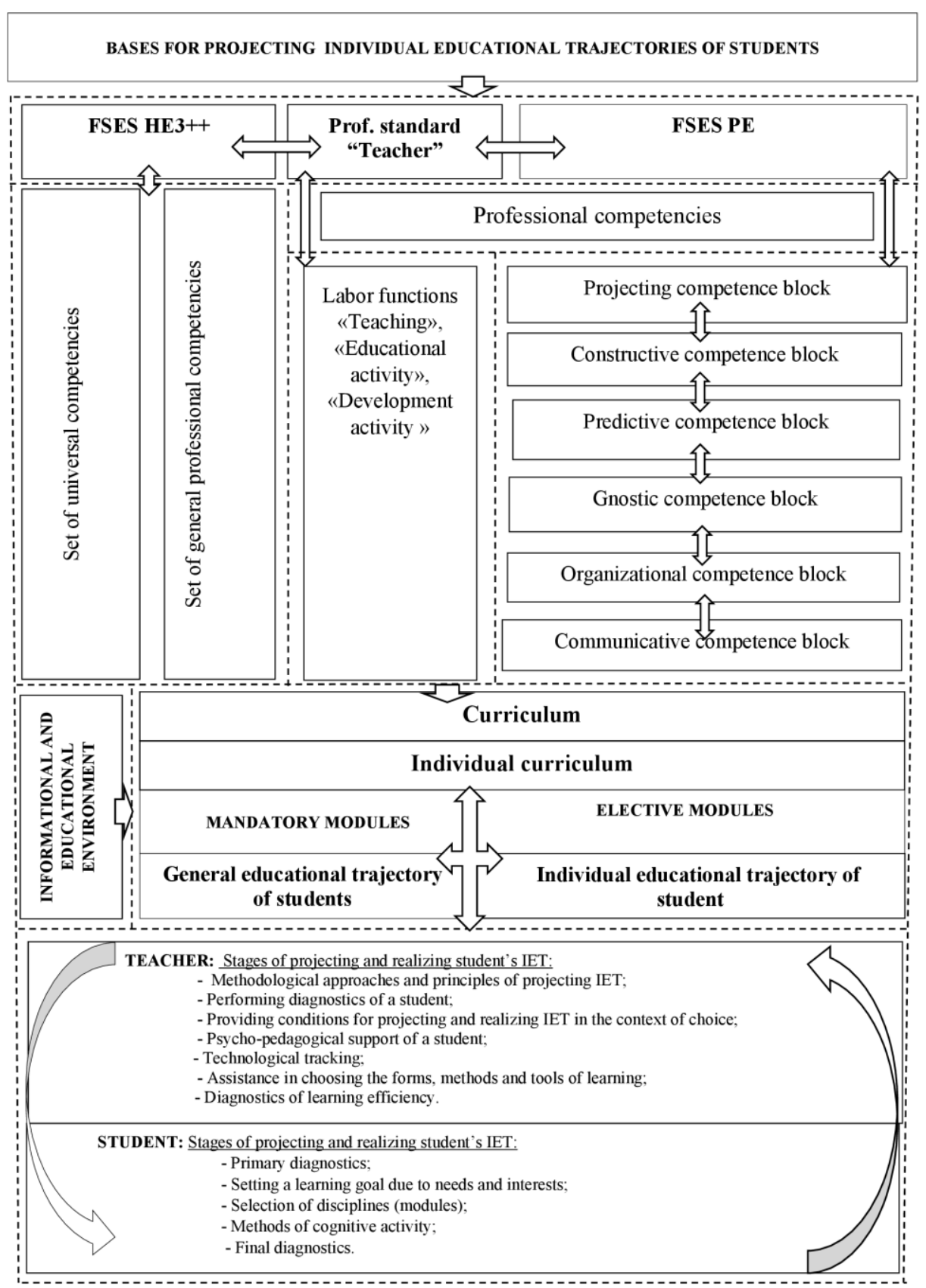

Figure 1. The bases for projecting individual educational trajectories of future preschool teachers

To make a substantiated choice of the bases for projecting individual educational trajectories, we used the method of group expert assessment (Shikhova, 2006; Shikhov, 2007; Valeeva et al., 2019), with the involvement of teachers and students of the correspondence department of the Institute of Psychology and Education of Kazan Federal University who have vocational secondary education and pedagogical experience in a preschool educational institution, as experts.

A fragment of one of questionnaires, used to interview experts, is presented in Table 1.

Table 1 


\section{Dear Colleague!}

In order to determine the bases for projecting individual educational trajectories of future teachers, you are kindly requested to take part in the given work as an expert.

Column 1 contains possible bases for projecting individual educational trajectories. Column 2 contains justification for their choice. Express your opinion in Column 3 by putting:

- $\quad$ sign " +", if you agree with the offered basis and justification for its choice given in column 2;

- $\quad$ sign “-”, if you do not agree;

- $\quad$ sign “?”, if you hesitate to answer.

State your comments, suggestions and additions in the "Notes" column.

\begin{tabular}{|c|c|c|c|}
\hline Basis for IET design & Justification & $\begin{array}{c}\text { Expert opinion } \\
\langle+» / \ll-» / ?\end{array}$ & Notes \\
\hline 1. & 2. & 3. & 4. \\
\hline FSES HE $3++$ & $\begin{array}{l}\text { It provides a basis of individual educational } \\
\text { trajectory, namely the content and scope of training, } \\
\text { which are established in the basic professional } \\
\text { educational program taking into account the } \\
\text { selected content of elective modules }\end{array}$ & & \\
\hline Professional standard & $\begin{array}{l}\text { It provides the structure of professional activity, } \\
\text { taking into account labor functions of a preschool } \\
\text { teacher such as "Teaching", "Personality } \\
\text { development activities", "Educational activities". } \\
\text { Each labor function is described in the individual } \\
\text { educational trajectory in terms of mastering the } \\
\text { basic professional educational program according } \\
\text { to the curriculum and within the set of } \\
\text { competencies developed by students }\end{array}$ & & \\
\hline Individual curriculum & $\begin{array}{l}\text { It is devised from mandatory, subject-specific and } \\
\text { elective disciplines selected by a student, as well as } \\
\text { the amount of academic hours required for their } \\
\text { mastering. It also determines the final learning } \\
\text { outcome that a student must achieve by graduation }\end{array}$ & & \\
\hline
\end{tabular}

The experts' examination showed that the following should be used as the bases for projecting individual educational trajectories of future teachers:

- Federal State Educational Standard of Higher Education (FSES HE $3++$ ) in the field of study 44.03.01 "Teacher education" (major "Preschool education");

- Professional standard "Teacher" (pedagogical activity in the field of preschool, primary general, basic general, secondary general education) (educator, teacher)";

- Federal state educational standard of preschool education;

- informational and educational environment of the university;

- individual curriculum; 
- a set of elective educational modules that meet the interests and level of knowledge of students;

- methodological approaches to projecting individual educational trajectories;

- principles of projecting individual educational trajectories;

- methods of students' cognitive activity during realization of individual educational trajectories.

The aim of the student's individual educational trajectory is shaped on the basis of existing regulatory documents: Federal State Educational Standard of Higher Education (FSES HE $3++$ );

Professional teacher's standard (pedagogical activity in the field of preschool, primary general, basic general, secondary general education) (educator, teacher); Federal State Educational Standard of Preschool Education (FSES PE).

Federal State Educational Standard of Higher Education (FSES HE $3++$ ) states the list of universal and general professional competencies of the graduate and determines the content and scope of training, which are recorded in the basic professional educational program of higher education, as well as suggests the selection of the contents of elective modules.

Professional standard marks the structure of the professional activity of a future specialist, who will be realizing an individual educational trajectory with regard to labor functions that he/she will perform in a preschool institution. Professional standard deals with such labor functions as "Teaching", "Educational activity", "Development activity". Each function is described in a student's individual educational trajectory by means of lexical expression of professional competencies.

While projecting an individual educational trajectory, the key element, that defines the structure and content of future teacher's professional competencies, is the federal state educational standard of preschool education, which sets the principles and objectives of preschool education. It provides an individual educational trajectory with the consistency of the requirements for the development of the full range of universal, general professional and professional competencies within their interconnected blocks: planning, practical, predictive, gnostic, organizational and communicative (Veretennikova, 2015), the indication of which stems from the peculiarities of work organization with preschool-age children.

Success of student's realization of an individual educational trajectory depends on the informational and educational environment created at the university. It should provide organizational and pedagogical conditions for individualization of training in accordance with students' learning needs and interests; as well as provide extensive information base, material and technical facilities for its effective use and positive impact on training.

An individual curriculum is devised from a set of mandatory, subject-specific and elective disciplines selected by a student in compliance with the amount of academic hours required for their acquisition. It also determines the final learning outcome that a student must achieve by graduation.

The mandatory part of the curriculum, which specifies the content and features of the organization of bachelor training (Table 2), is considered as a general educational trajectory. 
Table 2. Module elements of the mandatory part of the curriculum in future teachers' training (fragment)

\begin{tabular}{|c|c|c|c|c|c|}
\hline $\begin{array}{c}\text { Module } \\
\text { code }\end{array}$ & Module title & Discipline code & Module / Discipline content & Cr. & $\begin{array}{l}\text { Developed } \\
\text { competencies }\end{array}$ \\
\hline \multirow[t]{6}{*}{ M1M1 } & \multirow[t]{6}{*}{ Worldview module } & B1.M.01.01. & Philosophy & 2 & UC-5 \\
\hline & & B1.M.01.03. & $\begin{array}{l}\text { History (History of Russia, } \\
\text { General History) }\end{array}$ & 2 & UC-5 \\
\hline & & B1.M.01.04. & Sociology of Education & 2 & UC-5,GPC-2, 8 \\
\hline & & B1.M.01.05. & Economics of Education & 2 & UC-6,GPC-1, 2 \\
\hline & & B1.M.01.06. & Educational Law & 2 & UC-2,GPC-1, 3 \\
\hline & & B1.M.04.26. & $\begin{array}{l}\text { Concept of Modern Natural } \\
\text { Sciences }\end{array}$ & 2 & UC-1 \\
\hline \multirow[t]{2}{*}{ M2M2 } & \multirow{2}{*}{$\begin{array}{c}\text { Informational and } \\
\text { Technological } \\
\text { Module }\end{array}$} & B1.M.01.07. & $\begin{array}{l}\text { Information Technologies in } \\
\text { Education }\end{array}$ & 2 & UC-1,GPC-2, 5 \\
\hline & & B1.M.01.08. & $\begin{array}{l}\text { Bases of Mathematical } \\
\text { Treatment of Information }\end{array}$ & 2 & UC-1,GPC-2, 5 \\
\hline \multirow[t]{3}{*}{ M3M3 } & \multirow{3}{*}{$\begin{array}{l}\text { Communicative } \\
\text { Module }\end{array}$} & B1.M.01.02. & Foreign Language & 3 & UC-4 \\
\hline & & B1.M.04.27. & $\begin{array}{l}\text { Russian Language and } \\
\text { Communicative Culture }\end{array}$ & & $\mathrm{UC}-4$ \\
\hline & & B1.M.04.29. & Conflictology & & UC-3 \\
\hline \multirow[t]{3}{*}{ M4M4 } & \multirow{3}{*}{$\begin{array}{l}\text { Health Saving } \\
\text { Module }\end{array}$} & B1.M.01.09. & Health and Safety & & UC-8, GPC-1 \\
\hline & & B1.M.04.25. & Age Anatomy and Physiology & & GPC-1 \\
\hline & & B1.M.04.24. & Basic Medical Training & & GPC-3, 8 \\
\hline \multirow[t]{3}{*}{ M5M5 } & \multirow{3}{*}{$\begin{array}{l}\text { Psychological and } \\
\text { Pedagogical } \\
\text { Module }\end{array}$} & B1.M.03.01. & Fundamentals of Pedagogy & & UC-2, GPC-3, 7 \\
\hline & & B1.M.03.02. & $\begin{array}{l}\text { History of Pedagogy and } \\
\text { Education }\end{array}$ & & GPC-3, 4 \\
\hline & & B1.M.03.05. & General Psychology & & GPC- 4,7 \\
\hline
\end{tabular}

The aim of the general educational trajectory is the formation of universal, general professional and professional competencies required for the performance of the labor functions stated in the professional standard "Teacher", in accordance with demands placed on graduates targeting at professional activities in the system of preschool education.

The range of elective modules must meet the student's learning needs, interests and level of knowledge, so that the results of training could match his/her own educational goals and capability.

The contents of elective modules are determined by the graduate chair and created by participants of educational process. They (Table 2) are reflected in the content of individual curricula and corresponding individual educational trajectories (Table 3). 
Table 3. Elective modules in a future teacher's curriculum (fragment)

\begin{tabular}{|c|c|c|c|c|c|}
\hline $\begin{array}{c}\text { Module } \\
\text { code }\end{array}$ & Module title & $\begin{array}{c}\text { Discipline } \\
\text { code }\end{array}$ & Module / Discipline content & Cr. & \\
\hline \multirow[t]{13}{*}{ M2M8 } & \multicolumn{4}{|c|}{ Individualization of training (Elective modules) } & \multirow{13}{*}{ อัँ } \\
\hline & \multirow{4}{*}{$\begin{array}{l}\text { Elective module } 1 . \\
\text { Organization of } \\
\text { education for young } \\
\text { children }\end{array}$} & B1.M.04.08 & Pedagogy of Young Age & 2 & \\
\hline & & $\begin{array}{l}\text { B1.V.ED. } \\
05.02\end{array}$ & Technologies of work with young children & 2 & \\
\hline & & $\begin{array}{l}\text { B1.V.ED. } \\
05.01\end{array}$ & $\begin{array}{l}\text { Organization of collaboration of a teacher } \\
\text { with parents of young children }\end{array}$ & 2 & \\
\hline & & $\begin{array}{l}\text { B1.V.ED. } \\
05.01\end{array}$ & $\begin{array}{l}\text { Organization of the subject learning of } \\
\text { young children }\end{array}$ & 2 & \\
\hline & \multirow{4}{*}{$\begin{array}{l}\text { Elective module } 2 . \\
\text { Organization of } \\
\text { education in terms of } \\
\text { inclusion }\end{array}$} & B1.M.04.10 & $\begin{array}{l}\text { Inclusive education for preschool children } \\
\text { with health disabilities }\end{array}$ & 2 & \\
\hline & & B1.M.04.11 & $\begin{array}{l}\text { Projecting an individual educational path } \\
\text { for children with health disabilities }\end{array}$ & 2 & \\
\hline & & B1.M.04.15 & $\begin{array}{l}\text { Technologies of inclusive preschool } \\
\text { education }\end{array}$ & 2 & \\
\hline & & B1.M.04.15 & $\begin{array}{l}\text { Organization of collaboration of a teacher } \\
\text { with the family of children with health } \\
\text { disabilities }\end{array}$ & 2 & \\
\hline & $\begin{array}{l}\text { Elective module } 3 . \\
\text { Organization of } \\
\text { education for gifted } \\
\text { preschool children }\end{array}$ & $\begin{array}{l}\text { B1.V.ED. } \\
02.01\end{array}$ & $\begin{array}{l}\text { Anthropology of education for gifted } \\
\text { children }\end{array}$ & 2 & \\
\hline & & $\begin{array}{l}\text { B1.V.ED. } \\
03.01\end{array}$ & $\begin{array}{l}\text { Projecting an individual educational path } \\
\text { for gifted children }\end{array}$ & 2 & \\
\hline & & $\begin{array}{l}\text { B1.V.ED. } \\
03.02\end{array}$ & Technologies of work with gifted children & 2 & \\
\hline & & $\begin{array}{l}\text { B1.V.ED. } \\
03.02\end{array}$ & $\begin{array}{l}\text { Organization of tracking parents of gifted } \\
\text { preschool children }\end{array}$ & 2 & \\
\hline
\end{tabular}

Devising individual curricular for students enrolled in "Teacher education" (major "Preschool education"), provides them with the opportunity to efficiently develop competencies in accordance with FSES HE 3++. To achieve this goal, at the planning stage of an individual curriculum, universal, general professional and professional competencies are projected onto the platform of specific academic disciplines selected by a student. In case, these disciplines do not enable consistent development of all the necessary competencies, improvement of either their contents or the individual curriculum itself is carried out. Thus, an individual curriculum appears to have a flexible structure, although it requires careful consideration not only of students' competencies developed within its framework, but also the amount of hours of contact work with the teacher, as well as of self-study (within each discipline) for each year of training. It is advisable to plan interdisciplinary self-study of students, which is aimed at the formation and development of competencies, which are significant for their future professional activities. 


\section{Results}

Hence, an individual curriculum determines the sequence of acquisition of modules, order of practice-teach, state final certification and other types of educational activities with their indication in credits. It defines a form of interim certification of students for each module, discipline or practice. This plan should totally suit working programs of modules and course training elements that make up the modules, working programs of disciplines and practices. The draft of a student's individual curriculum is presented in Table 4.

Table 4. Individual curriculum of student

\begin{tabular}{|c|c|c|c|c|c|c|}
\hline \multicolumn{7}{|c|}{ Selection of educational modules within IET } \\
\hline $\mathrm{N}$ & $\begin{array}{c}\text { Modu } \\
\text { le } \\
\text { code } \\
\end{array}$ & Module Title & $\begin{array}{l}\text { Academic } \\
\text { discipline }\end{array}$ & Credit & Teacher & $\begin{array}{c}\text { Developed } \\
\text { competencies }\end{array}$ \\
\hline 1. & & & & & & \\
\hline 2. & & & & & & \\
\hline 3. & & & & & & \\
\hline & \multicolumn{5}{|c|}{ Total number of credits } & \\
\hline \multicolumn{7}{|c|}{ Student: } \\
\hline \multicolumn{7}{|c|}{$\begin{array}{l}\text { Tutor: } \\
\text { Academic office: } \\
\text { Date: }\end{array}$} \\
\hline
\end{tabular}

An individual educational trajectory (Table 5), delivering on an individual curriculum, is considered by us as a specific focus and consistent flow of educational-cognitive and subject-specific information in the learning activity of each student during achieving educational goals that satisfy his/her needs and interests. 
Table 5. Competencies developed within individual educational trajectories (fragment)

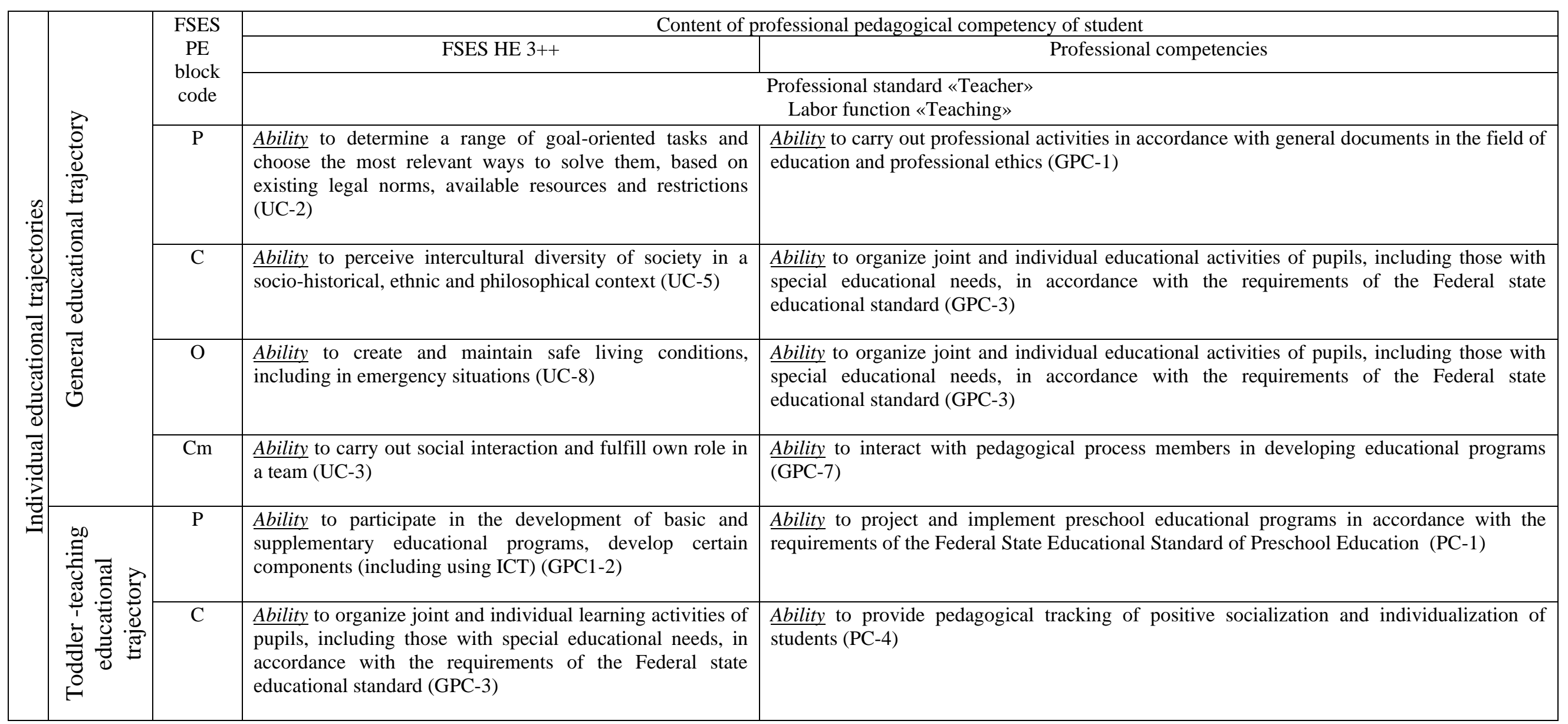


The survey of students and teachers conducted at KFU showed that there is a request for the following individual educational trajectories:

- an inclusive trajectory aimed at the formation of a comprehensive view of the professional activity of a teacher, which is connected with training and education of children with special educational needs;

- a creative trajectory involving the formation of professional and pedagogical competency in the field of training and education of children with advanced mental development or outstanding development of special abilities (musical, artistic, etc.).

- a toddler-teaching trajectory focused on solving pedagogical and professional tasks related to the education of toddlers (2-3 years).

The logic of the projecting process of an individual educational trajectory and within its framework the choice of ways of organizing students' training determines the following principles:

- professional targeting, which involves the transfer of educational and cognitive activities to professionally oriented ones during the study at individual educational trajectories;

- motivation as a driving factor of the development of professional skills of a person;

- self-organization, which means that a student purposefully manages his/her own training, displays activity, interest and strives for self-improvement;

- accelerated training, which provides the inclusion of long-term needs in the field of preschool education in the content of the student's individual educational trajectory.

Together the principles, which determine the direction and organization of the process of learning individualization, indicate the choice of methodological approaches to the projecting of individual educational trajectories.

The analysis of scientific pedagogical literature showed that such complementary approaches include: competency-based (aimed at implementing the principle of professional targeting); systematic (aimed at implementing the principles of professional targeting and accelerated training); module-based (provides the possibility of choosing elective module elements, which serves to realize the principle of student's selforganization); student-centered approaches (enables to take into account the student's educational needs; thus, to implement the principle of motivation). 
Learning by means of an individual educational trajectory requires the student to make certain thorough efforts to independently acquire knowledge, accumulate professional experience, and improve professionally significant personal qualities. In other words, a student is required to be personally active as a way of self-development. Obviously, for this it is necessary to provide appropriate methods of cognitive activity based on the use of intensive teaching technologies and allowing students to be involved in practice-oriented situations that arise in real professional teaching activity: game methods, situational analysis method, game design, case study method, method of self-esteem, brainstorming method and some others.

Thus, due to competent projecting, the realization of individual educational trajectories will lead to the formation of professional pedagogical competence of students, which is an integrative dynamic quality of future preschool teachers, developed from a basic level that provides each person with the opportunity to study at the next stages of education or carry out professional activity in a preschool organization, to a kind of "educational model" achieved through self-improvement and self-education.

\section{Discussions}

At present, the term "individual educational trajectory" is included in regulatory documents, becoming a cross-cutting element of the professional formation and development of a young specialist. The legal framework for training based on individual educational programs includes the Law "On Education in the Russian Federation" (article 50, para. 4), which states that "students of all educational institutions have the right to receive education in accordance with state educational standards; within these standards to study on individual curricula; have the right to an accelerated learning course. However, this does not regulate the agreement of individual curricula with existing curricula, as well as elective and compulsory parts of educational content.

The review of the scientific pedagogical literature showed that the following issues remain debatable and scantily studied:

- didactic adaptation of the basic educational program content of the field of study to the student's individual curriculum;

- balance between individual and cooperative learning activities of students, which foster the raising of their training quality; 
- substantiation of the professional competency body developed within the framework of an individual curriculum;

- timely provision of the university didactic system with advanced knowledge according to the achievements of modern science, etc.

From different points of view scholars (Zhesterev, 2018; Sazonov, 2011) consider the issues of determination of threshold values of student learning outcomes based on individual curricula, as well as formation of their assessment abilities, including formation of skills of adequate self-esteem.

It is obvious that individualization of training will require not only constant updating and devising a new curriculum, but also a change in the management scheme of student groups, which allows shifting the emphasis on the development of students' ability to independently organize their activities and the combination of autonomy with teamwork. Moreover, the success of this work will depend on the overcoming of contradictions between:

- unified requirements to learning outcomes established by FSES $3++$, and the need to provide students with the opportunity to purposefully choose an individual path of professional development and self-improvement;

- regulated forms of organization of the educational process at the university and the relevance of projecting individual educational trajectories of students, suggesting a certain autonomy of their training activity.

\section{Conclusion}

The methodological bases presented in this paper will promote a more systematic approach to projecting individual educational trajectories of future teachers, as well as in the context of territorial heterogeneity of resources in the educational sphere and specifics of Russian regions.

They establish the organizational and logical structure of students' training according to the individual curriculum, and its main characteristics such as scope, content, methods of cognitive activity, intended learning outcomes in the form of a body of universal, general professional and professional competencies which are most significant for a student's future professional activity.

The competencies, the development of which are tracked by individual educational trajectories of students, are determined by the requirements of the Federal State Educational Standard of Higher Education $3++$, 
the professional standard and the federal educational standard of preschool education with regard to the regional specificity defined by elective courses. These regulatory documents determine the blocks of competencies presented in the projecting bases for individual educational trajectories: planning, constructive, prognostic, gnostic, organizational and communicative.

In conclusion, we should note that the choice of the bases for projecting individual educational trajectories of future preschool teachers provides challenging opportunities for creating technologies of their implementation within university training.

\section{Acknowledgements}

The authors express their sincere gratitude to all teachers and students who took an active part in the pedagogical experiment.

\section{References}

Boyer, N. R., Langevin, S., \& Gaspar, A. (2008). Self-direction \& constructivism in programming education. Paper presented at the '08 proceedings of the 9th ACM SIGITE (Special Interest Group for Information Technology Education) Conference, New York, NY. doi:10.1145/1414558.1414585

Brockett, R. G., \& Hiemstra, R. (1991). Self-direction in adult learning: Perspective on theory, research, and practice. New York, NY: Routledge.

Choi, E., Lindquist, R., \& Song, Y. (2014). Effects of problem-based learning vs. traditional lecture on Korean nursing students' critical thinking, problem-solving, and self-directed learning. Nurse Education Today, 34, 52-56.

Dmitriev, G. D. (2010). Anatomy of an American University. Moscow: Shkol'nyye tehnologii.

Gayazov, A. S. (2010). Individual trajectories of person's education. Free Internet library. Retrieved March 02, 2020, from http://www.raop.ru/index.php?id=878

Kunash, M. A. (2013). An individual educational path of a student: methodical constructor, models, analysis. Volgograd: Uchitel'. 
Langshaw, S. J. (2017). Relationship between the self-efficacy and self-directed learning of adults in undergraduate programs (Doctoral dissertation, Capella University).

Lomakina, T. Yu. (2013) Conceptual approaches to the formation of the educational path of the personality in the system of continuing education. Otechestvennaya i zarubezhnaya pedagogika - Domestic and foreign pedagogy, 6(15), 69-77.

Loyens, S. M., Rikers, R. M., \& Schmidt, H. G. (2006). Students' conceptions of constructivist learning: A comparison between traditional and a problem-based learning curriculum. Advances in Health Sciences Education, 11, 365-379.

Maskaeva, A. M. (2011) Projecting individual educational trajectories of high school students in conditions of varied teaching in mathematics ( $\mathrm{PhD}$ dissertation, Moscow).

Molinari, A., Trevisan I., Bogdanova D., \& Akhmetova Yu. (2013). Classifying students based on fuzzy logic to devise individual study plans. Vestnik Ufimskogo gosudarstvennogo aviatsionnogo tekhnicheskogo universiteta - Bulletin of the Ufa State Aviation Technical University, 17(6), 43-46.

Phillips, B. N., Turnbull, B. J. \& He, F. X. (2015). Assessing readiness for self-directed learning within a non-traditional nursing cohort. Nurse Education Today, 35(3), e1-e7.

Postnikova, N. I. (2013). Organization of profile training for schoolchildren according to individual curricula (PhD dissertation, Moscow).

Sagimbayeva, G. S. (2015). Formation of an individual educational path of a future specialist in the context of a credit training system (on the example of the Republic of Kazakhstan) ( $\mathrm{PhD}$ dissertation, Barnaul).

Sazonov, B. A. (2011). Individually-oriented organization of the educational process as a requirement for modernization of higher education. Vyssheye obrazovaniye v Rossii- Higher Education in Russia, 4, $10-24$.

Shikhov, Yu. A. (2007). Qualimetry monitoring of fundamental training quality in technical university Stiks. ISTU. 
Shikhova, O. F. (2006). Basics of qualimetry of university educational standard. Izhevsk: Izdatel'stvo Udmurtskogo universiteta.

Spirina, T. A., \& Sagoyakova N. F. (2014). Foreign and domestic experience of individualization of education in higher education. Mir nauki, kul'tury, obrazovaniya - World of science, culture, education, 3 (46), 110-113.

Stockdale, S. L. (2003). Development of an instrument to measure self-directedness (Unpublished doctoral dissertation). University of Tennessee, Knoxville, TN.

Valeeva, R., Ziyatdinova, J., Osipov, P., Oleynikova, O., \& Kamynina, N. (2019). Assessing intercultural competence of engineering students and scholars for promoting academic mobility. Advances in Intelligent Systems and Computing, 917, 815-825.

Veretennikova, V. B. (2015). Structural and functional model of the quality of the competence-oriented educational process in the system of preschool education. Kazanskiy Pedagogicheskiy Zhurnal Kazan Pedagogical Journal, 5(2), 76-81.

Zeer, E. F., \& Zhurlova, E. Yu. (2017). Navigational aids as tools to support the development of competencies in the implementation of an individual educational trajectory. Obrazovaniye i nauka Education and Science, 19(3), 77-93.

Zhesterev, S. I. (2018). On some aspects of optimizing the formation and development of professional competencies through training based on individual module-based curricula. Mezhdunarodnyy nauchno-issledovatel'skiy zhurnal - International Research Journal, 5(71), 172-175.

Zhukova, N. M. (2006). Individualization and differentiation of teaching university students (PhD dissertation, Moscow). 